\title{
PENILAIAN TERHADAP RASIONALITAS PENGGUNAAN ANTIBIOTIKA PADA BALITA PENDERITA PNEUMONIA PUSKESMAS BOGOR UTARA
}

\author{
Lusi Indriani dan Oktaviana Zunnita \\ Program Studi Farmasi, FMIPA, Universitas Pakuan Bogor \\ Email: lusi.apoteker@gmail.com
}

Diterima : 1 September 2018

Direvisi : 23 November 2018

Disetujui : 14 Desember 2018

\begin{abstract}
ABSTRAK
Pneumonia adalah penyakit peradangan paru yang disebabkan oleh infeksi bakteri, virus, maupun jamur. Penyakit infeksi menular ini menjadi salah satu penyebab utama kematian pada balita di dunia. Pengobatan pneumonia dengan terapi antibiotika yang tepat dan rasional akan menentukan keberhasilan pengobatan. Penelitian ini bertujuan menilai rasionalitas penggunaan antibiotika pada balita penderita pneumonia di Puskesmas Bogor Utara periode Januari-Desember tahun 2016. Penilaian dilakukan berdasarkan metode Gyssens dengan melihat ketepatan indikasi, ketepatan pemilihan obat, ketepatan jangka waktu penggunaan, dan ketepatan dosis antibiotika. Hasil penilaian rasionalitas dengan metode Gyssens pada kategori V (tidak rasional karena tidak ada indikasi penggunaan antibiotika) adalah $0 \%$, kategori IVa (tidak rasional karena ada antibiotika lain yang lebih efektif) adalah 0\%, kategori IVd (tidak rasional karena ada antibiotika lain yang spektrumnya lebih sempit) 0\%, kategori IIIa (tidak rasional karena pemberian antibiotika terlalu lama) 0\%, kategori IIIb (tidak rasional karena pemberian antibiotika terlalu singkat) 9,6\%, katogeri IIa (tidak rasional karena dosis tidak tepat) sebanyak 43,8\%, serta kategori 0 (penggunaan antibiotika tepat/rasional) sebanyak 46,6\%. Dari semua kategori yang dinilai dapat disimpulkan bahwa di Puskesmas Bogor Utara, pemilihan antibiotika untuk pneumonia sudah rasional kecuali untuk kategori dosis dan lama atau jangka waktu pemberian yang tidak tepat/ rasional.
\end{abstract}

Kata kunci: Pneumonia, radang paru, antibiotika, metode Gyssens

\section{THE ASSESSMENT ON RATIONALITY OF ANTIBIOTICS USE FOR PNEUMONIA PATIENTS IN NORTH BOGOR HEALTH CENTER}

\begin{abstract}
Pneumonia is a lung inflammatory disease caused by bacteria, virus, and fungal infection. This contagious infectious disease is one of the leading cause of children death in the world. The appropriate and rational antibiotic medication will determine the success of pneumonia therapy. This study aimed to assess the rationality of antibiotic use in children suffering from pneumonia at Puskesmas Bogor Utara using database in period of January to December 2016. The study was carried according to the Gyssens method, by quantifying the accuracy of indication, drug selection, length of administration and antibiotic dosage as the parameters. The result showed that the value of indication of rationality category $\mathrm{V}$ (irrational because no indication of antibiotic usage) was $0 \%$, category IVa (irrational because there are other antibiotics more
\end{abstract}


effective) was $0 \%$, drug selection on IVd category (irrational because there are other antibiotics narrower spectrum) was $0 \%$ length of administratioan on category IIIa (irrational because antibiotics are too long given) was $9.6 \%$ and category IIIb (irrational due to antibiotics too short given) was $0 \%$, the antibiotic dosage on category IIa (irrational due to inaccurate dosage) was $43.8 \%$, and and rationality of antibitoc usage on category 0 (proper/ rational antibiotic usage) was $46.6 \%$. It can be concluded that antibiotic usage for pneumonia therapy in North Bogor Health Center was rational dosage was irrational in dosage and length of administration categories.

Keywords: Pneumonia, lung disease, antibiotic, Gyssens method

\section{PENDAHULUAN}

Pneumonia adalah penyakit peradangan paru yang disebabkan oleh infeksi bakteri, virus, maupun jamur (Junaidi, 2010). Pneumonia merupakan penyakit infeksi menular yang merupakan penyebab utama kematian pada balita di dunia. Data Kementerian Kesehatan tahun 2016 menunjukkan bahwa persentase penderita pneumonia pada balita di Indonesia dari tahun 2013 hingga 2015 cenderung mengalami peningkatan yaitu pada tahun 2013 berjumlah 24,46\%, kemudian pada tahun 2014 meningkat menjadi $29,47 \%$, dan pada tahun 2015 meningkat kembali menjadi 63,45\% (Kemenkes RI, 2016). Khusus untuk kota Bogor Jawa Barat, cakupan pneumonia pada balita pada tahun 2016 sebesar $69,7 \%$ dengan jumlah kasus yang ditemukan sebanyak 6.648 kasus (Dinas Kesehatan Kota Bogor, 2016).

Penyakit pneumonia pada balita perlu mendapatkan perhatian untuk menghindari dampak negatif dari penyakit tersebut. Dalam pengobatan pneumonia salah satunya dibutuhkan terapi antibiotika yang adekuat dengan berfokus pada diagnosis yang tepat. Pemilihan dan penggunaan antibiotika yang tepat dan rasional akan menentukan keberhasilan pengobatan untuk menghindari terjadinya resistensi bakteri (Juwita et al., 2017).

Penelitian terdahulu yang dilakukan di Puskesmas Kemiling kota Bandar Lampung pada periode Januari-Oktober tahun 2013, diperoleh kesesuaian dosis terhadap standar pengobatan pneumonia adalah 79,72\%, dan kesesuaian lama pengobatan terhadap standar pengobatan pneumonia adalah 81,95\% dari 184 kasus pneumonia pada balita (Advisedly et al., 2014). Penelitian oleh Nurzaki et al., (2015) menunjukkan bahwa penggunaan antiobiotik yang rasional untuk pengobatan pneumonia pada balita berdasarkan tepat indikasi sebanyak $100 \%$, tepat obat sebanyak $96,67 \%$, dan tepat dosis sebanyak $89,65 \%$ sehingga pemberian antibiotika yang rasional adalah sebanyak 86,67\% dari total 30 pasien balita pneumonia. Penelitian lain di RSUD Prof. Dr. W. Z. Johannes Kupang pada tahun 2015 menunjukkan hasil penilaian penggunaan antibiotika pada pneumonia balita kategori tepat pasien sebesar $100 \%$, tepat indikasi sebesar $100 \%$, tepat obat sebesar $21,95 \%$, tepat dosis sebesar $51,22 \%$, dan tepat lama pemberian sebesar 53,66\% (Anwar dan Horang, 2016).

Hal tersebut mendorong penulis untuk melakukan penilaian rasionalitas penggunaan antibiotika pada balita penderita pneumonia di Puskesmas Bogor Utara Kota Bogor periode tahun 2016. Pemilihan lokasi penelitian didasarkan pada data kesehatan kota Bogor tahun 2016 yang menunjukkan bahwa terdapat kenaikan jumlah penemuan kasus pneumonia pada balita dari tahun sebelumnya (2015) di wilayah kerja Puskesmas Bogor Utara yaitu dari 150 kasus, yang meningkat menjadi 207 kasus 
pada tahun 2016 (Dinas Kesehatan Kota Bogor, 2016).

\section{METODE PENELITIAN}

\section{Rancangan Penelitian}

Penelitian ini menggunakan metode observasional deskriptif dengan pendekatan retrospektif.

\section{Waktu dan Tempat Penelitian}

Penelitian dilaksanakan pada

bulanJuni hingga Agustus tahun 2017

bertempat di Puskesmas Bogor Utara Kecamatan Bogor Utara Kota Bogor.

\section{Sampel dan Populasi}

Sampel penelitian ini adalah rekam medis balita dengan diagnosis pneumonia periode Januari hingga Desember tahun 2016 yang memenuhi kriteria inklusi. Populasi dalam penelitian ini adalah jumlah seluruh rekam medis balita dengan diagnosis pneumonia yang menjalani pengobatan di Puskesmas Bogor Utara Kota Bogor pada periode Januari hingga Desember tahun 2016.

\section{Kriteria Inklusi dan Eksklusi}

Kriteria inklusi dalam penelitian ini yaitu peresepan antibiotika pada rekam medis balita dengan diagnosis pneumonia di Puskesmas Bogor Utara periode Januari hingga Desember tahun 2016. Kriteria eksklusi dalam penelitian ini yaitu peresepan antibiotika pada rekam medis pasien balita yang tidak lengkap untuk menilai rasionalitas.

\section{Teknik Pengumpulan Data}

Teknik pengumpulan data yang digunakan dalam penelitian ini adalah pengumpulan data sekunder yaitu dengan melihat rekam medis, register pasien, resep obat pasien balita dengan diagnosis pneumonia yang disesuaikan dengan kriteria inklusi. Instrumen penelitian dalam penelitian ini adalah lembar resep, register pasien, dan lembar rekam medis pasien.

\section{Analisis Data}

Analisis menggunakan kategori Gyssens (Kemenkes RI, 2011) untuk menilai rasionalitas penggunaan peresepan

antibiotika pada balita penderita pneumonia. Penilaian secara kualitatatif dilakukan dengan menggunakan metode Gyssens kemudian dikelompokkan ke dalam kategori yang sesuai.

Metode Gyssens dikategorikan sebagai berikut :

- Kategori 0 = penggunaan antibiotika tepat/bijak

- Kategori I = penggunaan antibiotika tidak tepat waktu

- $\quad$ Kategori IIa $=$ penggunaan antibiotika tidak tepat dosis

- Kategori IIb = penggunaan antibiotika tidak tepat interval pemberian

- Kategori IIc = penggunaan antibiotika tidak tepat cara/rute pemberian

- Kategori IIIa = penggunaan antibiotika terlalu lama

- Kategori IIIb = penggunaan antibiotika terlalu singkat.

- Kategori IVa = ada antibiotika lain yang lebih efektif

- Kategori IVb = ada antibiotika lain yang kurang toksik/lebih aman

- Kategori IVc = ada antibiotika lain yang lebih murah

- Kategori IVd = ada antibiotika lain yang spektrum antibakterinya lebih sempit

- Kategori V = tidak ada indikasi penggunaan antibiotika

- Kategori VI = data rekam medik tidak lengkap dan tidak dapat dievaluasi

\section{HASIL DAN PEMBAHASAN}

Jenis antibiotika yang digunakan pada balita dengan diagnosis pneumonia di Puskesmas Bogor Utara Kota Bogor periode Januari hingga Desember tahun 
2016 adalah Amoksisilin dan Kotrimoksazol. Jumlah pemakaian obat dapat dilihat pada Tabel 1. Fasilitas Pelayanan Kesehatan Tingkat Pertama, yang menyatakan bahwa pada penderita pneumonia pada anak dengan pengobatan rawat jalan, antibiotika lini pertama yang dapat diberikan yaitu amoksisilin atau kotrimoksazol (Menkes RI, 2015).

Tabel 1. Jenis Antibiotika yang Digunakan pada Balita Penderita Pneumonia Periode Januari - Desember Tahun 2016

\begin{tabular}{llll}
\hline No & Antibiotik & Jumlah & $\begin{array}{l}\text { Persentase } \\
(\%)\end{array}$ \\
\hline 1. & Amoksisilin & 58 & 79,5 \\
2. & Kotrimoksazol & 15 & 20,5 \\
\hline & Jumlah Total & 73 & 100 \\
\hline
\end{tabular}

Kedua antibiotika ini bekerja terhadap lebih banyak bakteri, baik bakteri gram negatif maupun bakteri gram positif (Tjay dan Rahardja, 2007). Amoksisilin merupakan antibiotika yang bersifat bakterisida bagi bakteri gram-positif dan gram negatif. Antibiotika ini aktif terhadap bakteri $S$. pneumoniae dan $H$. Influenzae yang merupakan bakteri patogen utama penyebab penyakit pada saluran pernapasan (Goodman \& Gilman, 2001).

\section{Evaluasi Penggunaan Antibiotik dengan Metode Gyssens}

Penilaian penggunaan antibiotika secara kualitatif dilakukan dengan menggunakan metode Gyssens kemudian dikelompokkan ke dalam kategori yang sesuai. Dari hasil analisis data diperoleh 73 kasus yang sesuai dengan kriteria inklusi seperti terlihat pada tabel 2.

Tabel 2. Penilaian Penggunaan Antibiotika Berdasarkan Metode Gyssens Pada Balita Penderita Pneumonia di Puskesmas Bogor Utara Kota Bogor Periode Januari Hingga Desember tahun 2016

\begin{tabular}{clcc}
\hline $\begin{array}{c}\text { Kategori } \\
\text { Gyssens }\end{array}$ & Definisi & Jumlah & Persentase (\%) \\
\hline VI & $\begin{array}{l}\text { Data Tidak Lengkap } \\
\text { Tidak rasional karena tidak ada indikasi } \\
\text { penggunaan antibiotika }\end{array}$ & 0 & 0 \\
IVa & $\begin{array}{l}\text { Tidak rasional karena ada antibiotika lain yang } \\
\text { lebih efektif }\end{array}$ & 0 & 0 \\
IVd & $\begin{array}{l}\text { Tidak rasional karena ada antibiotika lain yang } \\
\text { spektrumnya lebih sempit }\end{array}$ & 0 & 0 \\
IIIa & $\begin{array}{l}\text { Tidak rasional karena pemberian antibiotika } \\
\text { Ifrlalu lama }\end{array}$ & 0 & 0 \\
IIIb & $\begin{array}{l}\text { Tidak rasional karena pemberian antibiotika } \\
\text { terlalu singkat }\end{array}$ & 7 & 0 \\
IIa & $\begin{array}{l}\text { Tidak rasional karena dosis tidak tepat } \\
\text { 0 }\end{array}$ & 32 & 43,6 \\
& Penggunaan antibiotika tepat (rasional) & 34 & 46,6 \\
Jumlah Total & $\mathbf{7 3}$ & $\mathbf{1 0 0}$ \\
\hline
\end{tabular}

Hasil penilaian menunjukkan bahwa kategori VI (data tidak lengkap) sebanyak $0 \%$. Kategori V (tidak rasional karena tidak ada indikasi penggunaan antibiotika) adalah $0 \%$. Antibiotika yang diresepkan adalah amoksisilin dan kotrimoksazol.
Sebagian besar pneumonia disebabkan oleh bakteri, yang terjadi secara primer maupun sekunder setelah infeksi virus. Penyebab yang tersering adalah bakteri gram positif seperti Streptococcus pneumoniae. selain itu bakteri 
Staphylococcus aureus juga sering menyebabkan pneumonia (Corwin, 2008).

Hasil evaluasi dengan metode Gyssens pada kategori IVa (tidak rasional karena ada antibiotika lain yang lebih efektif) adalah 0\% karena pemilihan antibiotikanya sudah sesuai dengan Panduan Praktik Klinis Bagi Dokter di Fasilitas Pelayanan Kesehatan Tingkat Pertama, yang menyatakan bahwa pada penderita pneumonia anak dengan pengobatan rawat jalan, antibiotika lini pertama yang dapat diberikan yaitu amoksisilin atau kotrimoksazol (Menkes, 2015). Pada Kategori IVd (tidak rasional karena ada antibiotika lain yang spektrumnya lebih sempit) adalah $0 \%$, karena di Puskesmas Bogor Utara tidak ada balita dengan pneumonia yang menjalani kultur darah dikarenakan keterbatasan fasilitas laboratorium, sehingga pemberian antibiotika dilakukan secara empiris yaitu dengan pemberian amoksisilin dan kotrimoksazol. Penggunaan antibiotika secara empiris adalah penggunaan antibiotika pada kasus infeksi yang belum diketahui jenis bakteri penyebabnya. Tujuan pemberian antibiotika secara empiris adalah eradikasi atau penghambatan pertumbuhan bakteri yang diduga menjadi penyebab infeksi, sebelum diperoleh hasil pemeriksaan mikrobiologi. Pemilihan antibiotika pada terapi empiris didasarkan pada temuan sindrom klinis yang mengarah pada keterlibatan bakteri tertentu yang paling sering menjadi penyebab infeksi (Kemenkes RI, 2011).

Lama pemberian obat antibiotika yang diberikan dilihat berdasarkan aturan pakai obat dan jumlah obat yang diberikan dalam 1 kali pengobatan. Hasil penelitian menunjukkan bahwa dari 73 peresepan, lama pemberian antibiotika yang diberikan umumnya untuk 5 hari, 6 hari, dan 8 hari, sehingga pada kategori IIIa (tidak rasional karena pemberian antibiotika terlalu lama) adalah $0 \%$.
Umumnya Community Acquired pneumonia (CAP) diberikan terapi antimikroba selama 7-14 hari (Scalera and Thomas, 2007).

Pedoman Manajemen Terpadu Balita Sakit (MTBS) tahun 2015 menyatakan bahwa lama pemberian antibiotika untuk pengobatan pneumonia selama 3 hari atau 5 hari (Kemenkes RI, 2015). Hasil evaluasi menunjukkan bahwa sebanyak 7 peresepan $(9,6 \%)$ antibiotika pada pasien balita dengan diagnosis pneumonia termasuk kategori IIIb (tidak rasional karena pemberian antibiotika terlalu singkat). Hal ini terjadi karena umumnya pasien balita diberikan antibiotika kemasan botol $(60 \mathrm{ml})$ sehingga untuk anak dengan dosis $>125$ $\mathrm{mg} / 5 \mathrm{ml}$ untuk satu kali pemberian, maka jumlah tersebut hanya cukup untuk penggunaan selama 2,5 hari, sehingga lama pemberian antibiotika tidak sesuai standar pengobatan pneumonia.

Hal ini dapat menyebabkan terjadinya resistensi bakteri karena proses pengobatan yang tidak maksimal. Penelitian ini tidak jauh berbeda dengan yang sudah dilakukan pada penelitian sebelumnya di Puskesmas Kemiling kota Bandar Lampung dimana kesesuaian lama pengobatan terhadap standar pengobatan pneumonia adalah $81,95 \%$, yaitu sebanyak $18,05 \%$ lama pengobatan tidak sesuai dari 184 kasus pneumonia pada balita (Advisedly et al., 2014). Penelitian lain di RSUD Prof. Dr. W. Z. Johannes Kupang mengenai rasionalitas pengobatan pneumonia balita pada tahun 2015 menunjukkan bahwa jumlah kasus yang tepat lama pemberian sebesar 53,66\%, sehingga yang tidak tepat lama pemberian adalah 46,34\% (Anwar dan Horang, 2016).

Untuk penilaian kategori IIa (Tidak rasional karena dosis tidak tepat) terdapat sebanyak tiga puluh dua peresepan 
$(43,8 \%)$. Perhitungan dosis dalam penelitian ini dilakukan berdasarkan berat badan pasien, dimana berat badan pasien didapatkan dari data rekam medik pasien maupun pada resep obat. Hasilnya menunjukkan bahwa sebagian dosis antibiotika yang diberikan kurang dari dosis yang disarankan. Sebagai contoh ketidaksesuaian dosis yang diberikan pada balita berumur 2 tahun 5 bulan dengan berat badan $8,5 \mathrm{~kg}$ mendapatkan amoksisilin sirup dengan aturan pakai $3 \mathrm{x}$ sehari $3 / 4$ sendok teh, dimana 1 sendok teh (5 mL) mengandung amoksisilin sebesar 125 mg. Berdasarkan pedoman farmakoterapi Dipiro (2009) bahwa dosis antibiotika amoksisilin untuk pengobatan pneumonia yaitu $40 \mathrm{mg}-90 \mathrm{mg} /$ $\mathrm{Kgbb} / \mathrm{hari}$ dalam 3 dosis terbagi. Sedangkan dosis penggunaan kotrimoksazol pada anak sebesar 8- 10 $\mathrm{mg} / \mathrm{kg} /$ hari komponen TMP dibagi dalam 2 dosis (IDAI, 2016). Berdasarkan pedoman tersebut dosis amoksisilin minimal yang seharusnya diberikan kepada pasien dengan berat badan $8,5 \mathrm{~kg}$ untuk sekali minum adalah 113,33 mg. Dari peresepan menunjukkan bahwa dosis yang diberikan untuk sekali minum balita tersebut hanya $93,75 \mathrm{mg}$, sehingga dosis amoksisilin yang diberikan pada pasien tersebut kurang dari dosis yang seharusnya.

Pada penelitian di Puskesmas Kemiling kota Bandar Lampung periode Januari-Oktober tahun 2013 diperoleh kesesuaian dosis terhadap standar pengobatan pneumonia adalah $79,72 \%$ dari 184 kasus pneumonia pada balita sehingga ketidaksesuaian dosis sebanyak 20,28\% (Advisedly et al., 2014). Penelitian lain di RS PKU Muhammadiyah Yogyakarta tahun 2013, menunjukkan bahwa penggunaan antiobiotika yang tepat dosis adalah sebanyak $89,65 \%$, sehingga yang tidak tepat dosis adalah 10,35\% dari 30 kasus pneumonia pada balita (Nurzaki et al.,
2015). Berbeda dengan penelitian di RSUD Prof. Dr. W. Z. Johannes Kupang mengenai rasionalitas pengobatan pneumonia balita pada tahun 2015 menunjukkan bahwa jumlah kasus yang tepat dosis adalah 51,22\%, sehingga ketidaktepatan dosis sebesar 48,78\% (Anwar dan Horang, 2016).

Penggunaan antibiotika disebut rasional jika memenuhi kriteria tepat diagnosis, tepat indikasi obat, tepat pemilihan obat, tepat dosis, tepat cara pemberian, tepat lama pemberian, tepat interval waktu pemberian, tepat harga, tepat informasi, tepat tindak lanjut, tepat penyerahan obat, tepat penilaian kondisi pasien, pasien patuh terhadap perintah pengobatan yang dibutuhkan, dan waspada efek samping (Kemenkes RI, 2011). Hasil evaluasi dari peresepan antibiotika dengan metode Gyssens yang termasuk dalam kategori 0 (penggunaan antibiotika tepat/ rasional) adalah 46,6\% (34 peresepan).

Penelitian ini menggunakan data retrospektif, sehingga terdapat beberapa keterbatasan dalam penelitian. Diantaranya seperti pada proses pengambilan data terdapat data pasien yang kurang lengkap atau hilang, sehingga sampel yang diperoleh terbatas. Metode ini juga memiliki kekurangan karena waktu kejadian sudah berlalu sehingga tidak dapat dilakukan konfirmasi, atau tidakan pencegaham dengan memberikan rekomendasi pengobatan yang tepat kepada dokter. Peneliti juga tidak dapat menilai hasil pengobatan terhadap kesembuhan pasien.

\section{KESIMPULAN}

Hasil penilaian rasionalitas penggunaan antibiotika untuk terapi pneumonia pada balita menggunakan metode Gyssens diperoleh hasi untuk kategori V (indikasi), kategori IV (pemilihan antibiotika), dan kategori IIIa (pemberian antibiotika terlalu lama) 
adalah sebanyak $0 \%$ (tidak ada) berturutturut sehingga penggunaan antibiotika untuk kategori tersebut adalah rasional. Sedangkan kategori IIIb (pemberian antibiotika terlalu singkat) terdapat sebanyak 9,6\% (7 peresepan), kategori IIa (dosis tidak tepat) sebanyak 43,8\% (32 peresepan), dan kategori 0 (penggunaan antibiotika yang tepat/ rasional) sebanyak 46,6\% (34 peresepan) sehingga dapat dinyatakan tidak rasional.

\section{UCAPAN TERIMA KASIH}

Terimakasih sebesar-besarnya kepada Dokter Devi Fitriyanti dan Bayu Kurniawan yang telah membantu dalam pengambilan data.

\section{DAFTAR PUSTAKA}

Advisedly, A.A. Tarigan dan M.M. Berawi. 2014. Kajian peresepan antibiotika penyakit pneumonia pada balita di puskesmas kemiling Kota Bandar Lampung pada periode Januari-Oktober tahun 2013. Jurnal Kedokteran Universitas Lampung. 3(4): 18-26.

Anwar, Y. dan M.E.B.B. Horang. 2016. Evaluasi penggunaan antibiotika pada pengobatan penderita pneumonia anak di instalasi rawat inap RSUD Prof. Dr. W. Z. Johannes Kupang periode JanuariJuni 2015. Jurnal Farmasi Indonesia. 13(02): 252-260.

Corwin, E. J. 2008. Buku Saku Patofisiologi (Handbook

of Pathophysiology). Buku

Kedokteran EGC. Jakarta.

Dinas Kesehatan Kota Bogor. 2016. Profil Kesehatan Kota Bogor Tahun 2016. Dinas Kesehatan Bogor.

Dipiro, J.T., B.G. Wells, T.L.Schwinghammer dan C.V. Dipiro. 2009. Pharmacoterapy Handbook Seventh Edition. Mc Graw Hill Medical. New York.
Goodman dan Gilman.

2001. The Pharmacological Basis of Therapeutics Edisi 10 Volume 3. Penerjemah: Hardman, J. G. dan Limbrid, L. E. Penerbit Buku Kedokteran EGC. Jakarta.

IDAI, 2016. Buku Saku Dosis Obat Pediatri. Ikatan Dokter Anak Indonesia. Jakarta.

Junaidi, I. 2010. Penyakit Paru dan Saluran Napas. PT Bhuana Ilmu Populer. Jakarta.

Juwita, D.A.J., H. Arifin dan N. Yulianti. 2017. Kajian deskriptif retrospektif regimen dosis antibiotika pasien pneumonia anak di RSUP. Dr. M. Djamil Padang. Jurnal Sains Farmasi \& Klinis. 3(2): 128-133.

Kemenkes RI. 2011. Modul Penggunaan Obat Rasional. Bina Pelayanan Kefarmasian. Jakarta.

Kemenkes RI. 2015. Buku Bagan Manajemen Terpadu Balita Sakit (MTBS).

Kemenkes RI. 2016. Profil Kesehatan Indonesia Tahun 2015. Sekertariat Jenderal Kesehatan Republik Indonesia. Jakarta.

Menkes RI. 2015. Keputusan Menkes RI Nomor. HK. 02.02/MENKES/514/2015 Tentang Panduan Praktik Klinis Bagi Dokter Di Fasilitas Pelayanan Kesehatan Tingkat Pertama. Kemenkes RI. Jakarta.

Nurzaki, A., B. Rahajeng, dan S. Orbayinah. 2015.

Evaluasi Kerasionalan Penggunaan Antibiotika Untuk Pengobatan Pneumonia Pada Balita Rawat Inap di RS PKU Muhammadiyah Yogjakarta Periode JanuariDesember 2013. Naskah Publikasi Karya Tulis Ilmiah Universitas Muhammadiyah Yogyakarta. Yogyakarta.

Scalera, N. M. and Thomas M. F. 2007. How Long Should We Treat Community-Acquired Pneumonia. 
Lippincott Williams \& Wilkins. USA.

Tjay, T. H. dan K. Rahardja. 2007. Obat-

Obat Penting Khasiat, Penggunaan, dan Efek-Efek Sampingnya Edisi VI. PT. Elex Media Komputindo. Jakarta. 